\title{
Age, Correlation, and Provenance of the Neoproterozoic Skelton Group, Antarctica: Grenville Age Detritus on the Margin of East Antarctica
}

\author{
R. J. Wysoczanski and A. H. Allibone \\ Research School of Earth Sciences, Australian National University, Australian Capital Territory 0200, \\ Australia, and Institute for Frontier Research on Earth Evolution, Japan Marine Science \\ and Technology Centre, Yokosuka, Kanagawa 237-0061, Japan \\ (e-mail: richardw@jamstec.go.jp)
}

\begin{abstract}
A B S T R A C T
Detrital zircon U-Pb ages constrain the age and provenance of the Skelton Group in southern Victoria Land, one of several Proterozoic-Cambrian metasedimentary units that form basement to the Ross Orogen in East Antarctica. The age of the youngest detrital zircons combined with previous dating of crosscutting intrusive rocks indicates deposition of the northern and southern parts of the Skelton Group between ca. 1050-535 and ca. 950-551 Ma, respectively. Many zircons in the northern part of the Skelton Group crystallized after partial melting during upper amphibolite facies metamorphism at ca. 505-480 Ma, although older ca. 550-Ma metamorphic zircon rims indicate an earlier episode of high-grade metamorphism. Detrital zircon ages from the Skelton Group are dominated by ca. 1300-950Ma ages similar to those in the Beardmore Group in East Antarctica and the Adelaidean succession of South Australia, suggesting that these rocks are generally correlative. Zircons that crystallized at ca. $1050 \mathrm{Ma}$ form the major age population of the northern Skelton Group, while a broader range of Neoproterozoic zircons form significant components in other sediments deposited on the margin of East Antarctica-Australia at this time, indicating a close proximity to exposed Grenville age crust. Inferred basement rocks of Grenville age beneath the Ross Orogen in East Antarctica (represented by a potential $1049 \pm 11$-Ma orthogneiss), Paleozoic cover in eastern Australia, and ice in Marie Byrd Land in West Antarctica are potential sources for the Grenville age component in these Neoproterozoic sedimentary rocks.
\end{abstract}

Online enhancement: table.

\section{Introduction}

Metasedimentary rocks that form basement to the extensive Cambro-Ordovician Ross Orogen in East Antarctica and the Delamerian Orogen in South Australia (fig. 1) were deposited during one or more phases of Neoproterozoic-Cambrian rifting that accompanied breakup of the Precambrian supercontinent Rodinia (e.g., Ireland et al. 1998; Preiss 2000; Goodge et al. 2002). These rocks include the Beardmore Group in the central Transantarctic Mountains, Skelton Group in southern Victoria Land, basement to the Wilson Terrane in northern Victoria Land, and the Adelaidean succession in South 2004.

Manuscript received June 30, 2003; accepted January 12,

${ }^{1}$ School of Earth Sciences, James Cook University of North Queensland, Townsville Q4811, Australia.
Australia (fig. 1). Determining the age and provenance of these sedimentary rocks provides constraints on the timing of rifting during the breakup of Rodinia and the arrangement of older cratonic blocks within Rodinia. Research thus far indicates that Neoproterozoic-Cambrian sedimentation was a prolonged and complex series of events, not all of which were related to rifting or the breakup of Rodinia (e.g., Preiss 2000; Myrow et al. 2002). The position of older cratons within Rodinia is still debated, with particular emphasis on determining whether western Laurentia was once juxtaposed against East Antarctica-Australia (e.g., Sears and Price 1978, 2000; Dalziel 1991; Hoffman 1991; Moores 1991; Ross et al. 1992; Brookfield 1993; Li et al. 1995; Burnett and Berry 2000; Wingate and 


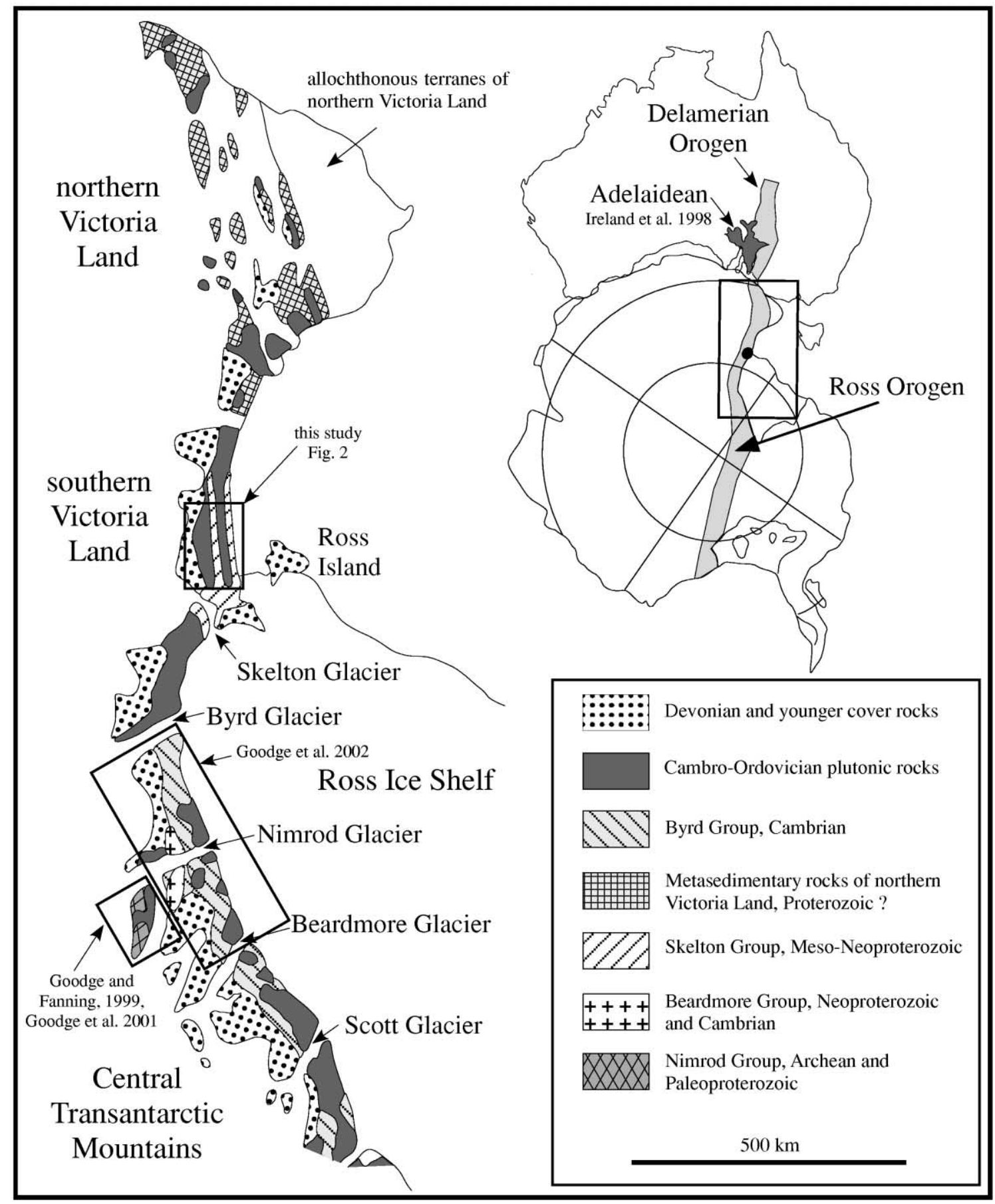

Figure 1. Location and geologic map of the Transantarctic Mountains, Antarctica, showing the metasedimentary units discussed in the text. The inset shows the position of Adelaidean rocks and the Delamerian (Australia) and Ross (Antarctica) Orogens before Cretaceous-Cenozoic rifting, with the black circle indicating the study area. The locations of other recent geochronological studies in the Transantarctic Mountains and South Australia relevant to the discussion are indicated. 
Giddings 2000; Goodge et al. 2001; Karlstrom et al. 2001; Duebendorfer 2002; Pisarevsky et al. 2003).

Ages of detrital zircons in sedimentary rocks and radiometric ages of coeval volcanic rocks provide constraints on the timing of sedimentation and likely source terranes for Neoproterozoic and Cambrian sedimentary rocks in South Australia (e.g., Ireland et al. 1998) and the Central Transantarctic Mountains (Goodge et al. 2002; fig. 1). In South Australia, at least five cycles of rifting, sedimentation, and minor related igneous activity occurred between ca. 827 and $520 \mathrm{Ma}$ (e.g., Wingate et al. 1998; Gravestock and Shergold 1999; Preiss 2000), with continental separation occurring at ca. 820$800 \mathrm{Ma}$ (Pisarevsky et al. 2003), before ca. $755 \mathrm{Ma}$ (Wingate and Giddings 2000), or after ca. $700 \mathrm{Ma}$ (Preiss 2000). Sedimentation in South Australia terminated with the onset of Delamerian plutonism at $514 \pm 7 \mathrm{Ma}$ (Foden et al. 1999). In the Central Transantarctic Mountains, rifting and associated sedimentation occurred after ca. $1065 \mathrm{Ma}$, the age of the youngest detrital zircons in the Beardmore Group, and were partly synchronous with mafic magmatism at $668 \pm 1 \mathrm{Ma}$ (Goodge et al. 2002). Other sedimentary rocks in the Central Transantarctic Mountains (Byrd Group) are supracrustal rocks younger than ca. $512 \mathrm{Ma}$ deposited during the onset of uplift and erosion associated with the Cambro-Ordovician Ross Orogen (Goodge et al. 2002; Myrow et al. 2002).

This article provides SHRIMP U-Pb dates from detrital zircons that constrain the age and provenance of the Skelton Group in southern Victoria Land, approximately a third of the way between the Central Transantarctic Mountains and the Adelaidean rocks of South Australia when CretaceousCenozoic rifting between Australia and Antarctica is restored (Flottmann et al. 1993; fig. 1). The zircon ages are compared with those from the Adelaidean succession and Beardmore and Byrd Groups to propose correlations between metasedimentary rocks and determine any large-scale similarities or differences in their provenance. U-Pb dating of metamorphic overgrowths on detrital zircons and igneous zircons in migmatites from Skelton Group samples that were affected by upper amphibolite facies metamorphism constrains the timing of high-grade metamorphism during the Ross Orogen in southern Victoria Land.

\section{Basement Geology in Southern Victoria Land}

Basement Skelton Group metasedimentary rocks in southern Victoria Land (fig. 2) comprise distinct northern and southern structural-metamorphic do- mains (Findlay et al. 1984) separated by the Frio Shear Zone (Cook 1997), which is largely covered by the Walcott Glacier (fig. 2). The northern part is characterized by a north-northwest-striking structural grain that is evident in both metasedimentary and plutonic rocks (Findlay et al. 1984; Allibone et al. 1991, 1993a; Cox 1993). Structures, metasedimentary units, and granitoid plutons can be traced as continuous features for many tens of kilometers in some cases. The southern part comprises several disparate and possibly allochthonous blocks that are generally only $1-10 \mathrm{~km}$ in size (Cook and Craw 2001, 2002). Each block has distinct lithologic, structural, and metamorphic characteristics and is separated by amphibolite facies ductile shear zones that were active during the Ross Orogen (Cook and Craw 2001). Bounding shear zones and the internal structure of individual blocks locally define a northeast-striking structural grain that is distinct from the north-northweststriking structural grain of the northern part of the Skelton Group.

Development of the north-northwest-striking structural grain in the northern part of the Skelton Group coincided with peak upper amphibolite facies metamorphism $\left(650^{\circ}-750^{\circ} \mathrm{C}\right.$, 4-6 kb; Allibone 1992; Cox 1992), partial melting of many metasedimentary rocks (Allibone and Norris 1992), and emplacement of voluminous concordant low $\mathrm{Sr} / \mathrm{Y}$ (LOSY; Tulloch and Kimbrough, in press) calcalkaline granitoid plutons (DV1a suite) at $500 \pm$ $6 \mathrm{Ma}$ (Allibone et al. 1993b; Cox 1993; Encarnacion and Grunow 1996; Cox et al. 2000; Allibone and Wysoczanski 2002). Minor high Sr/Y (Tulloch and Kimbrough, in press; DV1b suite) granitoid orthogneiss bodies as old as $535 \pm 10 \mathrm{Ma}$ (Allibone and Wysoczanski 2002) were emplaced before the voluminous LOSY plutonism that coincided with peak metamorphism. These gneissic intrusions cut the northern part of the Skelton Group, indicating that deposition of these rocks occurred before $535 \pm 10 \mathrm{Ma}$. Further, more widespread high Sr/Y and potassic, alkali-calcic plutonism (DV2 suite) occurred at ca. 490 and ca. $480 \mathrm{Ma}$, respectively, after peak metamorphism in the northern part of the Skelton Group (Allibone et al. 1991, 1993a, 1993b; Smillie 1992; Turnbull et al. 1994; Encarnacion and Grunow 1996).

Metamorphic grades in the southern part of the Skelton Group vary between upper greenschist and lower-midamphibolite facies. Primary depositional features are preserved locally, reflecting lesser degrees of strain and textural reconstitution than metasedimentary rocks in the northern part (Grindley and Warren 1964; Skinner 1982; Cook and Craw 


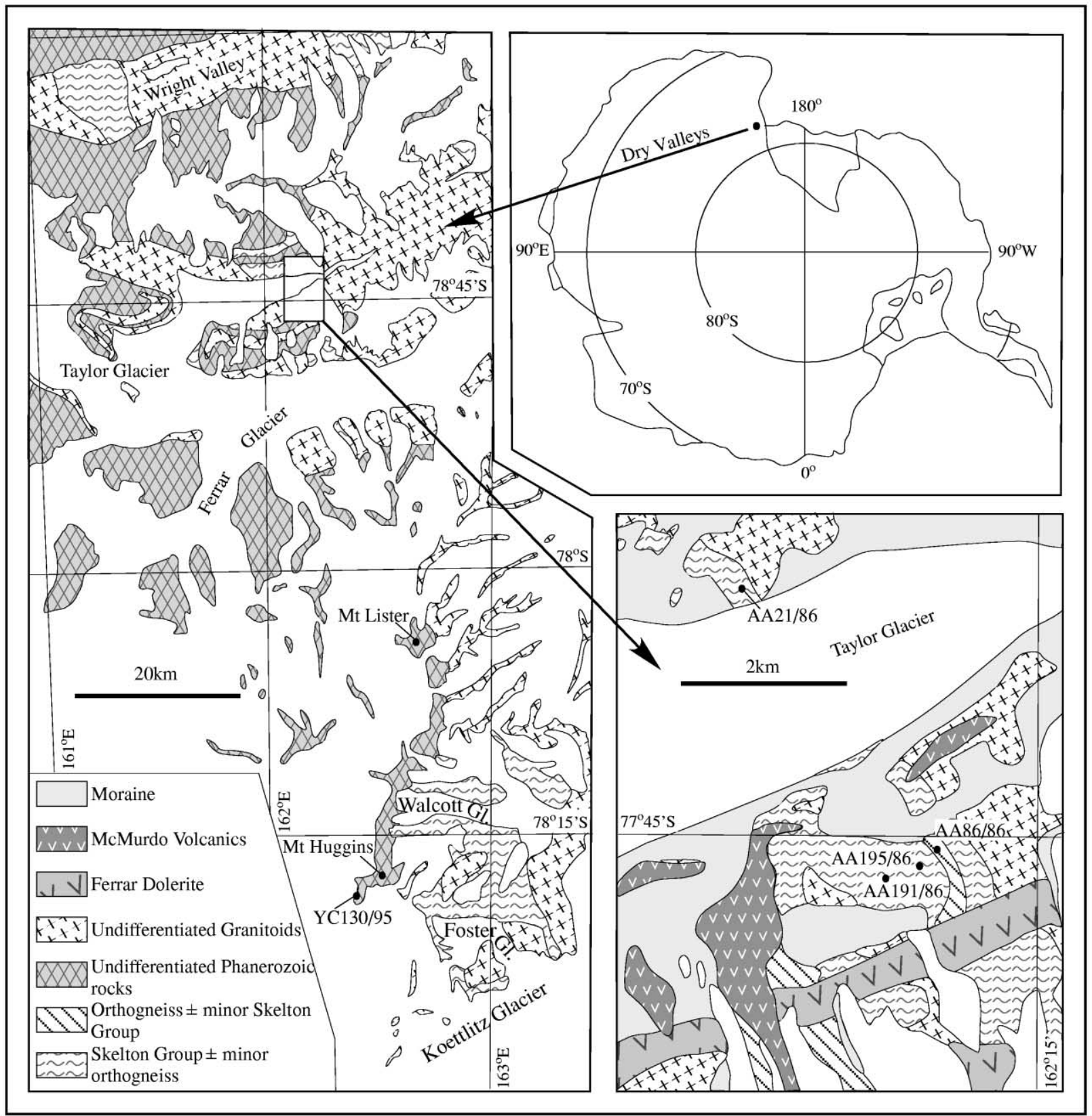

Figure 2. Geologic map of the Dry Valleys region, southern Victoria Land, showing sample localities

2001, 2002). Granitoid and dioritoid plutons emplaced between ca. 551 and $535 \mathrm{Ma}$ (Rowell et al. 1993; Encarnacion and Grunow 1996; Mellish et al. 2002; Read et al. 2002) cut the southern part of the Skelton Group, indicating that sedimentation occurred before $551 \pm 4 \mathrm{Ma}$. Sm-Nd dating of pillow basalts from near the Skelton Glacier (Rowell et al. 1993) implies deposition of the Skelton Group in this area coincided with Neoproterozoic subaqueous volcanism at ca. $750 \mathrm{Ma}$.
Metasedimentary rocks in southern Victoria Land were initially described as the Skelton Group (Gunn and Warren 1962) and subsequently divided into separate Skelton and Koettlitz Groups on the basis of perceived differences in metamorphic grade rather than age or provenance (Grindley and Warren 1964). Amphibolite facies rocks thought to be prevalent north of the Koettlitz Glacier (fig. 2) were included in the Koettlitz Group, while greenschist facies rocks thought to be confined to the Skelton 
Glacier (fig. 1) area were named the Skelton Group. Cook and Craw (2001) indicate that the Koettlitz Group (as originally defined) includes rocks with a wider range of metamorphic grades than was previously realized and consequently recommend abandoning the name Koettlitz Group while retaining Skelton Group for all metasedimentary rocks in southern Victoria Land deposited before the Cambro-Ordovician Ross Orogen.

\section{Sample Description}

Detrital zircon ages were obtained from four samples of the Skelton Group in the Taylor Valley and a fifth sample from the southwest side of Mount Huggins (fig. 2). The Taylor Valley and Mount Huggins lie within the northern and southern parts of the Skelton Group, respectively. The samples therefore provide data on the age and provenance of rocks in both parts of the Skelton Group. The four samples from the northern Skelton Group span the compositional range of quartzofeldspathic rocks in this location (Allibone 1988), allowing the consistency of detrital zircon ages to be compared between different lithologies. All primary sedimentary features in samples from the northern Skelton Group were obliterated during multiple phases of ductile deformation, metamorphism, and hydrous partial melting.

Sample AA195/86 (fig. 2) is a folded migmatitic quartzofeldspathic gneiss that contains numerous millimeter- to centimeter-wide veins of leucosome material. The metamorphic mineral assemblage includes quartz, plagioclase (An 18-28), K-feldspar, and biotite. Migmatitic rocks such as AA195/86 lack orthopyroxene or peritectic garnet, implying partial melting at $650^{\circ}-700^{\circ} \mathrm{C}$ via a hydrous melting reaction rather than dehydration or fluid-absent melting at $800^{\circ} \mathrm{C}+$ (e.g., Waters 1988; Nair and Chacko 2002). Trace amounts of manganoan orthopyroxene in nearby rare nonmigmatitic rocks likely formed in parts of the rock mass where insufficient $\mathrm{H}_{2} \mathrm{O}$ was present to flux melting and is therefore not indicative of granulite facies conditions sensu stricto (Allibone 1988).

Sample AA21/86 (fig. 2) is from a layer of migmatitic K-feldspar-rich paragneiss inferred to have originally been an arkosic sandstone. The mineral assemblage includes K-feldspar, plagioclase, quartz, and trace amounts of biotite. Sufficient partial melting occurred during peak metamorphism for the rock to lose its structural coherency, with intercalated refractory calc-silicate and amphibolite layers now forming isolated disrupted xenoliths within the paragneiss. The high degree of partial melting is reflected in the subhedral to euhedral shape of plagioclase grains that are enclosed by interstitial K-feldspar and quartz (Allibone 1988).

Sample AA86/86 (fig. 2) is a migmatitic semipelitic schist that contains biotite, plagioclase (An 22-25), garnet, and minor K-feldspar. Leucosomes include both quartz-plagioclase only and quartzplagioclase-K-feldspar-bearing varieties that likely formed at different times and under different metamorphic conditions during the rocks history (Allibone 1988).

Sample AA191/86 (fig. 2) is a discordant leucogranite dike inferred to be a product of partial melting of the Skelton Group during peak metamorphism at $500 \pm 6 \mathrm{Ma}$ (Encarnacion and Grunow 1996; Cox et al. 2000; Allibone and Wysoczanski 2002). Similar structurally controlled dikes occur throughout the hinge of a kilometer-scale fold on the southern side of the Taylor Valley that developed during peak metamorphism and emplacement of the adjacent Bonney Pluton at $500 \pm 6 \mathrm{Ma}$ (Allibone and Norris 1992). The annite-rich composition of biotite, LOSY geochemistry (Tulloch and Kimbrough, in press), and distinct structural setting is consistent with an anatectic petrogenesis (Allibone 1988), although the sample appears similar to dikes of the younger DV1b suite granodiorite. Dating of zircons was undertaken to constrain the time of peak metamorphism as well as the age and provenance of the protolith.

Sample YC130/95 was collected from immediately below the Kukri Erosion Surface (which separates Phanerozoic cover rocks from underlying basement) on the western side of Mount Huggins (fig. 2). It is a coarse sandstone metamorphosed at greenschist facies conditions in which primary sand grains are still readily recognizable in hand specimen, indicating significantly less textural reconstitution and relatively low-grade metamorphism compared with the four samples from the northern Skelton Group. Comparison with the northern Skelton Group samples shows the effects of high-grade metamorphism on the zircon age spectra.

\section{Acquisition and Interpretation of Zircon Ages}

Zircons were extracted for U-Pb dating by SHRIMP following the standard operating procedures (e.g., Williams and Claesson 1987; Ireland 1992) of the Research School of Earth Sciences, Australian National University. Analyses of ca. 50 zircon grains per sample were obtained using an $\mathrm{O}_{2}$ primary ion beam of 4-5 nA, which produced an analytical spot of ca. $30 \mu \mathrm{m}$ width. Analyses were performed with 
four scans through the mass range and calibrated to the internal standard AS3 (Paces and Miller 1993).

Individual ages of zircons are given as ${ }^{206} \mathrm{~Pb} / 238 \mathrm{U}$ ages for zircons younger than ca. $800 \mathrm{Ma}$ and ${ }^{207} \mathrm{~Pb} /$ ${ }^{206} \mathrm{~Pb}$ ages for older zircons as the precision of the ages for each isotopic system changes at ca. $800 \mathrm{Ma}$ (Ireland 1992). Zircons from Skelton Group metasediments exhibit a large spread of ages from Cambrian to Archean, and some samples in particular have a large proportion of zircons with discordant ages. To avoid ages biased by discordant analyses, a filter is used similar to that of Hallsworth et al. (2000). Weighted mean ages are given at the 95\% confidence level $(2 \sigma)$, and individual ages given in table 1 (in the online edition of the Journal of Geology) and figure 3 are at the $66 \%$ confidence level $(1 \sigma)$.

Before analysis, cathodoluminescence (CL) imaging was undertaken to determine heterogeneity within the grains. This allowed the ion beam to be placed within single domains of the zircons, thus avoiding overlap of areas of differing age. Further high-quality postanalysis images (used in fig. 5) were also taken. Although the vast majority of analyses were found to be on single domains, some analyses did overlap two age domains. The results of these overlapped analyses on the age spectra are discussed further.

\section{Results}

Sample YC130/95. All of the zircons analyzed from sample YC130/95 have ages that are $>80 \%$ concordant (fig. 3). Mesoproterozoic zircons dated at ca. 1500-900 Ma dominate the age spectra. The main peaks within this age range occur at $942 \pm$ $4 \mathrm{Ma}(n=6, \mathrm{MSWD}=0.81), 1063 \pm 9 \mathrm{Ma}(n=$ 7 , MSWD $=1.03)$, and $1315 \pm 11 \mathrm{Ma}(n=5$, MSWD $=1.02$ ). Other Mesoproterozoic zircons include individual grains with ages of ca. $1420 \mathrm{Ma}$, ca. $1500 \mathrm{Ma}$, and ca. $1515 \mathrm{Ma}$. Smaller numbers of zircons with a wide range of Archean and Paleoproterozoic ages are also present. Ages include ca. $1740 \mathrm{Ma}(n=3)$, ca. $1860 \mathrm{Ma}(n=3)$, ca. 2040 $1950 \mathrm{Ma}(n=4)$, ca. $2135 \mathrm{Ma}(n=2)$, and $2700 \mathrm{Ma}$ $(n=3)$ and individual Proterozoic and Archean ages (fig. 3a). Zircon Th/U ratios (fig. 4a) show a large range and no trend with age.

Sample AA195/86. The majority of zircons in sample AA195/86 are euhedral prismatic grains that display fine oscillatory zoning (fig. 5). They yielded concordant ages with a weighted mean ${ }^{207} \mathrm{~Pb} /{ }^{206} \mathrm{~Pb}$ age of $1049 \pm 11 \mathrm{Ma} \quad(n=38$, MSWD $=1.02$ ) and have $\mathrm{Th} / \mathrm{U}$ ratios between 0.37 and 0.63 (fig. $4 b$ ) that are typical of magmatic zircons (Williams and Claesson 1987; Hanchar and Millar 1993). Many grains have narrow rims $<20$ $\mu \mathrm{m}$ wide that are dark and featureless under CL imaging (fig. 5). Two rims (grain 32.1) large enough to be analyzed give concordant ${ }^{206} \mathrm{~Pb} / 238 \mathrm{U}$ ages of ca. 532 and $553 \mathrm{Ma}$ and have low $\mathrm{Th} / \mathrm{U}$ ratios of 0.03 and 0.06 (fig. $4 b$ ) that imply rim growth during Cambrian metamorphism associated with the Ross Orogen. The restricted range of zircons in this sample is unusual and resembles the zircon suite of a magmatic rather than a metasedimentary rock despite the sample being collected from what appears to be a metasedimentary sequence.

Three grains with concordant ages (analyses 16.1, 21.1, and 44.1) and one with a slightly discordant age (analysis 12.1) have apparent ${ }^{207} \mathrm{~Pb} /{ }^{206} \mathrm{~Pb}$ ages of ca. $800 \mathrm{Ma}$. CL imaging shows that in each case the area analyzed overlaps the magmatic interior and narrow metamorphic rim, and therefore these are mixed ages that are not considered to be geologically meaningful.

Sample AA21/86. Sample AA21/86 contains four texturally distinct types of zircon. These are clear euhedral oscillatory-zoned grains (e.g., fig. 5, grains 1 and 33), corroded cores of zircon grains that appear to have been partially melted (e.g., grain 4.1 core), irregularly shaped dark metamict zircons (e.g., grain $4.1 \mathrm{rim}$ ), and particularly broad rims that range from a few to a hundred microns wide (e.g., grain 3.1). The clear euhedral oscillatory-zoned zircon grains have $\mathrm{Th} / \mathrm{U}$ ratios of $0.36-0.70$ (fig. $4 c$ ) and give a weighted mean ${ }^{207} \mathrm{~Pb} /{ }^{206} \mathrm{~Pb}$ age of $1056 \pm 21 \mathrm{Ma}(n=17, \mathrm{MSWD}=0.95)$. The textural character and $\mathrm{Th} / \mathrm{U}$ ratios of these zircons imply an igneous origin (Williams and Claesson 1987; Hanchar and Millar 1993). Dark rims of four zircons give a concordant weighted mean ${ }^{206} \mathrm{~Pb} /{ }^{238} \mathrm{U}$ age of $495 \pm 15 \mathrm{Ma}$. Th/U ratios of $0.16-0.39$ are generally lower than the Proterozoic igneous grains but greater than metamorphic rims on zircon grains analyzed in AA195/86, perhaps reflecting the relatively high degree of partial melting in the metaarkose gneiss compared with the quartzofeldspathic gneiss AA195/86. The metamict rims and corroded zircon cores have a wide range of discordant ages of ca. 600-500 and 1200-1000 Ma, respectively (fig. 3c). Two grains (analyses 30.1 and 36.1) have apparent concordant ages of ca. 890 and ca. $870 \mathrm{Ma}$. However, they have large errors, and the analytical spots overlapped dark rims and igneous cores, resulting in mixed ages.

Sample AA86/86. Sample AA86/86 contains clear euhedral zircons with distinct oscillatory zoning and rounded equant grains that comprise cor- 

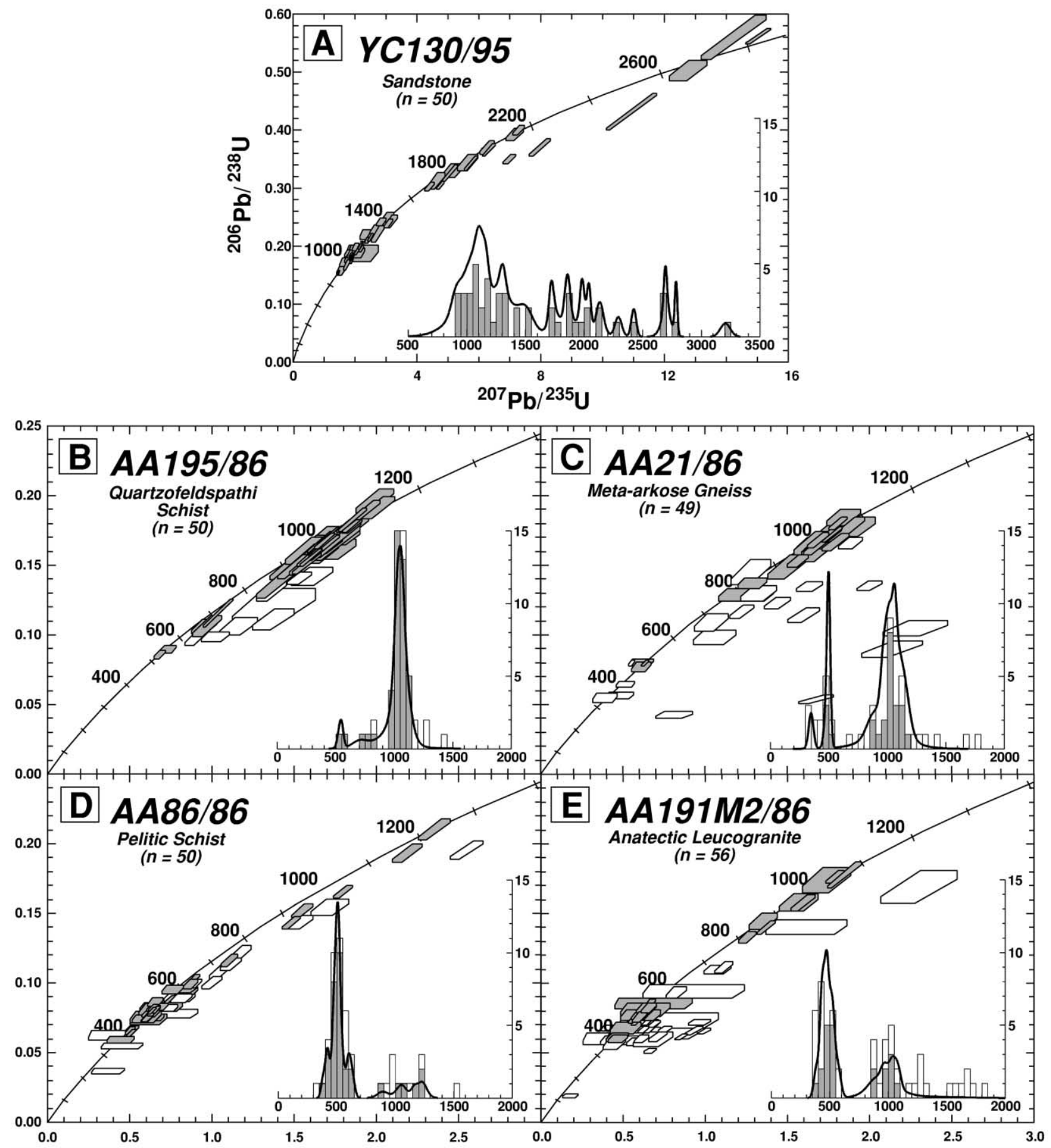

Figure 3. U-Pb concordia diagrams of detrital zircon ages from metasedimentary rocks of the Skelton Group, with insets of cumulative probability plots and histograms. Concordia diagram is of ${ }^{204} \mathrm{~Pb}$ corrected data, whereas probability plots and histograms are a mix of ${ }^{207} \mathrm{~Pb} /{ }^{206} \mathrm{~Pb}$ and ${ }^{206} \mathrm{~Pb} /{ }^{238} \mathrm{U}$ ages as discussed in the text. Analyses that are $>80 \%$ concordant are shown as solid symbols in all plots, and these are used in age calculations. Discordant analyses $\mid<80 \%$ concordant) are shown as open symbols, are filtered from age calculations (cf. Hallsworth et al. 2000), and are not discussed as peaks in the age spectra. Individual analyses are plotted at $1 \sigma$ error. 

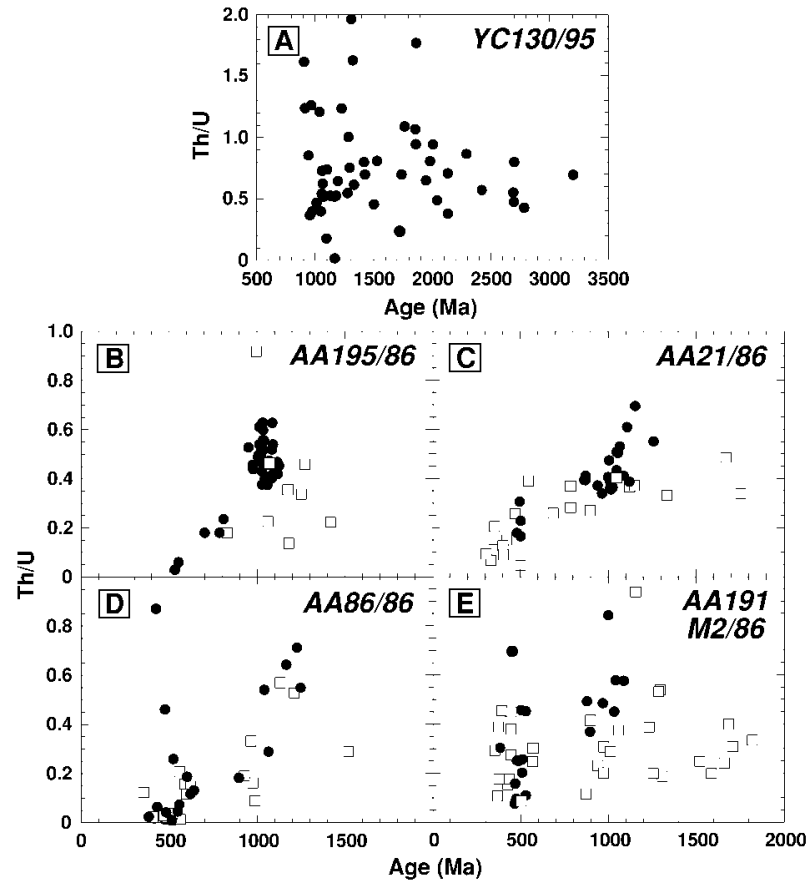

Figure 4. U/Th ratios of zircons from Skelton Group metasedimentary rocks. Analyses of zircons with discordant ages are shown as open symbols and with concordant $(>80 \%)$ ages as solid symbols. Note the general trend of higher ratios for older grains (ca. $1 \mathrm{Ga}$ ) and lower ratios for younger grains (ca. $500 \mathrm{Ma}$ ) exhibited by zircons with concordant ages, reflecting an igneous source for older zircon and either metamorphic origin or metamorphic + magmatic origin for younger zircon. Zircons of apparent ca. 800-Ma age have intermediate $\mathrm{Th} /$ $\mathrm{U}$ ratios reflecting a mix of young ca. 1-Ga and ca. 500Ma age components.

roded, partially melted cores surrounded by relatively wide clear rims that are either oscillatory zoned or dark and featureless (e.g., fig. 5, grains 7 and 13). Analyses of the euhedral grains and thick rims on the rounded grains are concordant and give a weighted mean ${ }^{206} \mathrm{~Pb} /{ }^{238} \mathrm{U}$ age of $502 \pm 4 \mathrm{Ma}$ $(n=18$, MSWD $=1.37)$. Four grains with apparently younger ages (e.g., analysis 12.1) are interpreted to have suffered $\mathrm{Pb}$ loss, resulting in a lower age. $\mathrm{Th} / \mathrm{U}$ ratios of ca. 500-Ma zircons, including those characterized by oscillatory zoning, are generally low with all except three ranging from 0.0 to 0.2 (fig. 4d), implying that they formed during partial melting at the peak of metamorphism. Four other grains have concordant apparent ages of ca. 650-550 Ma, which are considered to be geologically meaningless because the analytical areas overlapped rims and corroded cores (e.g., analysis 7.1).
Variably corroded cores of the rounded grains give concordant Proterozoic ages of ca. $1050 \mathrm{Ma}(n=$ 2), $1160 \mathrm{Ma}$, and $1230 \mathrm{Ma}(n=2)$. These cores have $\mathrm{Th} / \mathrm{U}$ ratios $>0.29$, which is higher than the oscillatory-zoned grains that formed at ca. $500 \mathrm{Ma}$.

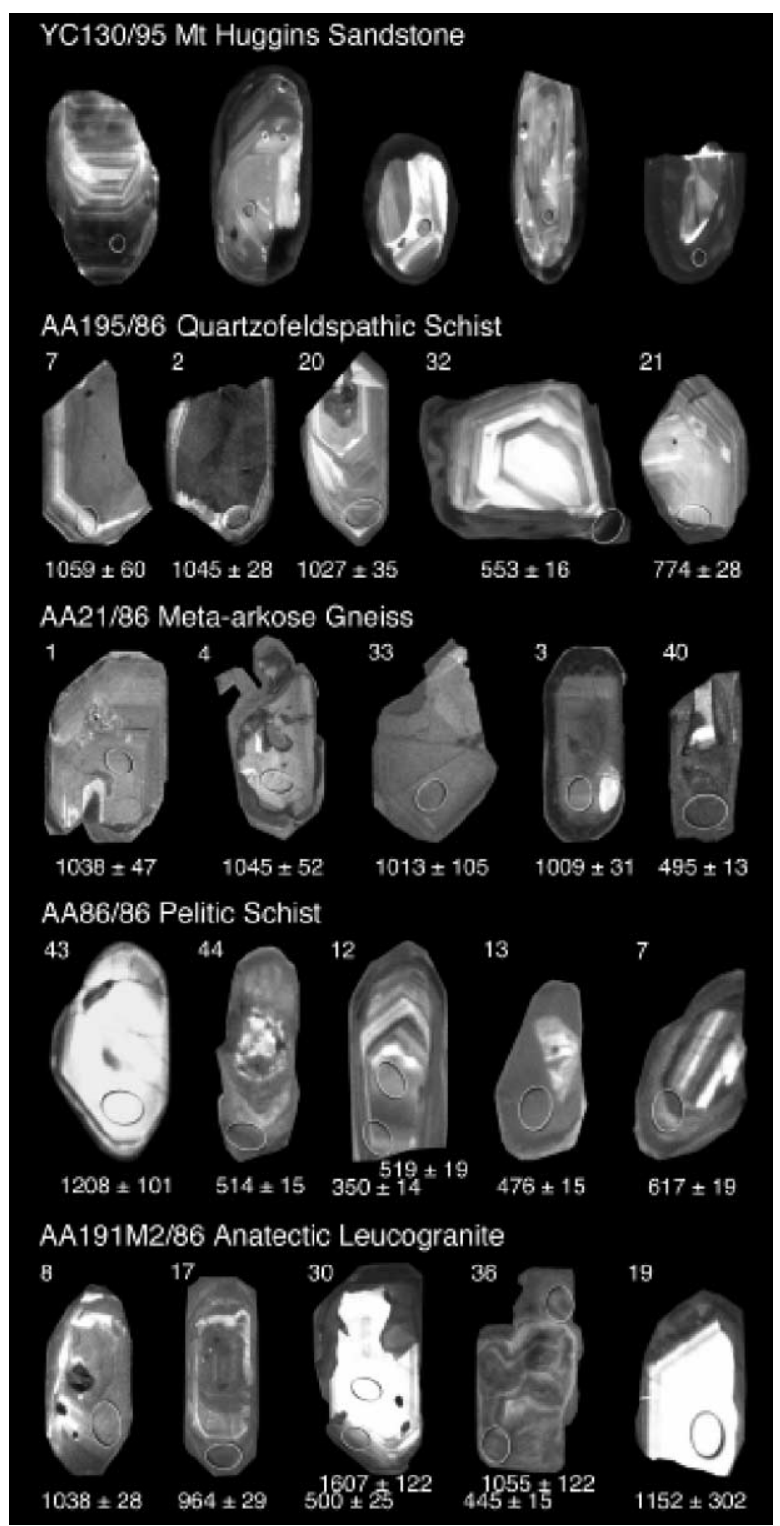

Figure 5. Cathodoluminescence images of zircons analyzed, with ion probe spots, grain numbers, and ages. Exact locations of analyses for YC130/95 are not known. Ages shown are preferred ages, as discussed in the text. The scale is given by the analytical areas, which are approximately $30 \mu \mathrm{m}$ across. Many grains exhibit oscillatory zoning, typical of magmatic zircons, whereas dark featureless rims may be metamorphic in origin. Note also the metamict nature of some grains and corroded cores of others. 
Sample AA191M2/86. The majority of zircon grains from AA191M2/86 have dark metamict and corroded, partially melted cores surrounded by thin either oscillatory-zoned or dark and featureless euhedral rims (fig. 5). A small proportion of zircons are clear oscillatory-zoned euhedral grains. The metamict state of most zircons is expected in a leucogranite derived from the surrounding rocks during upper amphibolite facies metamorphism. Greater than half of the zircons analyzed were metamict and yielded discordant ages.

Zircon grains with concordant ages include those with ca. 500- and ca. 1100-1000-Ma ages. Nine of the 13 younger grains give a weighted mean ${ }^{206} \mathrm{~Pb} /$ ${ }^{238} \mathrm{U}$ age of $494 \pm 7 \mathrm{Ma}$ (MSWD $=1.62$ ). These analyses include euhedral zircon rims that surround metamict cores (e.g., fig. 5, grain 30.1) and clear euhedral grains. Four apparently younger grains are interpreted to have undergone $\mathrm{Pb}$ loss. $\mathrm{Th} / \mathrm{U}$ ratios of ca. 500-Ma zircons are $0.07-0.70$ (fig. $4 e)$.

Neoproterozoic zircons include rounded and clear euhedral grains with oscillatory zoning and high $\mathrm{Th} / \mathrm{U}$ ratios of $0.37-1.58$. Five of the eight analyses give a weighted mean ${ }^{207} \mathrm{~Pb} /{ }^{206} \mathrm{~Pb}$ age of $1055 \pm 33 \mathrm{Ma}(\mathrm{MSWD}=0.64)$.

\section{Discussion}

Origin and Significance of Cambro-Ordovician Zircons in the Skelton Group. Cambro-Ordovician zircons occur in the four samples from the northern part of the Skelton Group that have undergone upper amphibolite facies metamorphism but are absent from the sample from the southern Skelton Group (Mount Huggins), which has been subjected to only greenschist facies metamorphism. CambroOrdovician zircons occur as homogeneous rims or, more rarely, as oscillatory-zoned rims around Precambrian zircon cores, some of which have been corroded. Th/U ratios of the Cambro-Ordovician zircons tend to be significantly lower than those that characterize Precambrian zircons. Oscillatoryzoned Cambro-Ordovician zircons with higher Th/ $\mathrm{U}$ ratios are confined to samples that show textural evidence and field relationships indicative of higher degrees of partial melting during metamorphism (AA21/86, AA191/86). These textural and compositional features are consistent with the CambroOrdovician zircon rims having formed on detrital grains during metamorphism of the Skelton Group.

The ca. 500-Ma age of the Cambro-Ordovician zircons in the Skelton Group is significantly younger than the $535 \pm 10$-Ma age of the Dun Pluton, which intrudes the Skelton Group adjacent to the Ferrar Glacier (fig. 2), and at least marginally younger than the $516 \pm 10-\mathrm{Ma}$ age of the Calkin Pluton, which intrudes the Skelton Group in the Taylor Valley (Allibone and Wysoczanski 2002). The age of Cambro-Ordovician zircons in the Skelton Group is indistinguishable from that of the voluminous DV1a suite plutonic rocks emplaced at $500 \pm 6$ Ma during the peak of metamorphism (Encarnacion and Grunow 1996; Cox et al. 2000; Allibone and Wysoczanski 2002).

The ca. 532- and 552-Ma zircon rims in AA195/ 86 most likely indicate onset of relatively highgrade metamorphic conditions as early as ca. 550 $\mathrm{Ma}$, several tens of millions of years before peak metamorphism at $500 \pm 6 \mathrm{Ma}$. A prolonged episode, or several successive episodes of higher-grade metamorphism, would be consistent with the presence of multiple generations of migmatites in the Skelton Group (Allibone 1988).

Depositional Age and Correlation of the Skelton Group. Abundant Mesoproterozoic-Neoproterozoic zircons dated at ca. 1300-950 Ma are present in the sample from the southern part of the Skelton Group, while samples from the northern part of the Skelton Group contain zircons with concordant ages of ca. $1050 \mathrm{Ma}$. The absence of younger detrital zircons indicates deposition after ca. 950 and 1050 $\mathrm{Ma}$ in the southern and northern parts of the Skelton Group, respectively. The $551 \pm 4-$ Ma crosscutting granitoid plutons near the Skelton Glacier (Rowell et al. 1993; Encarnacion and Grunow 1996) provide a minimum depositional age for the southern part of the Skelton Group, while the $535 \pm$ 10-Ma Dun Pluton constrains the minimum depositional age of the northern part of the Skelton Group. The presence of metamorphosed basaltic pillow lavas with a Nd-Sm model age of ca. $750 \mathrm{Ma}$ interlayered with the Skelton Group near the Skelton Glacier (Rowell et al. 1993) implies a Neoproterozoic rather than Mesoproterozoic depositional age for at least the southern part of the Skelton Group.

The southern Skelton Group sample has a significantly larger component of Mesoproterozoic zircons compared with the northern Skelton Group, which suggests that the Frio Shear Zone, which marks the boundary between the northern and southern parts of the Skelton Group, may represent a significant provenance boundary. Furthermore, the absence of zircons dated at ca. 900-550 $\mathrm{Ma}$ in all samples is consistent with the recent reinterpretation of the Neoproterozoic Beardmore Orogen (Grindley and McDougall 1969) as a minor event in the early history of the Cambro-Ordovician Ross Orogen (Goodge 1997). 
Metasedimentary rocks that form basement to other parts of the Ross and Delamerian Orogens are potential correlatives of the Skelton Group. Recent work examining stratigraphic relationships and ages of units within the Beardmore and Byrd Groups in the Central Transantarctic Mountains, located 250-500 km south of the Skelton Group (fig. 1; Goodge et al. 2002; Myrow et al. 2002), has allowed for clarification of correlations with the Skelton Group. Detrital zircon ages and stratigraphic relationships indicate that the Beardmore Group was deposited between $1065 \pm 65$ and ca. $532 \mathrm{Ma}$, a similar time span as the Skelton Group. The Byrd Group, including the Shackelton Limestone (523-512 Ma) and the overlying siliciclastic rocks derived from the active Ross Orogen $\mid<512$ $\mathrm{Ma})$, is younger than the Skelton Group and has no obvious correlative in southern Victoria Land, although volcanic equivalents of some granitoid rocks emplaced during the Ross Orogen have recently been identified in the base of the Beacon Supergroup (Wysoczanski et al. 2003). Beardmore Group rocks were largely derived from Mesoproterozoic and older (>1400 Ma) rocks with a significant component of Archean zircons in the basal Cobham Formation (Goodge et al. 2002). Only minor amounts of ca. 1300-1000-Ma zircons are present in the Beardmore Group, although Goodge et al. (2002) were able to recognize distinct ca. 1095and ca. 1220-Ma zircon populations. The diverse range of zircon ages present in the Beardmore Group is broadly similar to the detrital zircon ages from the southern part of the Skelton Group (although the relative proportions of particular ages are different), which is compatible with correlation of these rocks.

There are no detrital zircon ages for Neoproterozoic metasedimentary rocks in northern Victoria Land that would allow a direct comparison with the Skelton Group (fig. 1). However, Black and Sheraton (1990) describe ca. 1100-Ma-old xenocrystic zircons within a ca. 540-Ma-old granitoid derived by partial melting of the Rennick Schist, which is a part of the metasedimentary basement of northern Victoria Land. These ages coupled with dating of the timing of schistosity development (ca. $530 \mathrm{Ma}$; Adams 1986) constrain the age of basement schists in the Wilson Terrane to between ca. 1100 and $540 \mathrm{Ma}$, similar to the range defined for the Skelton and Beardmore Groups. The presence of ca. 1100-Ma zircons implies that Grenville age crust may also have formed an important part of the provenance of the Rennick Schist.

Ireland et al. (1998) analyzed detrital zircons from the Neoproterozoic-Cambrian Adelaidean sedi- mentary rocks of southeastern Australia (fig. 1) and documented systematic variations in detrital zircon ages over time. Zircons with ages greater than ca. $1550 \mathrm{Ma}$ dominate the older formations deposited at ca. 827-700 Ma. Younger formations deposited at ca. 700-600 Ma contain progressively greater proportions of ca. 1200-1000-Ma zircons, with the uppermost Bonney Sandstone containing ca. 12001000-Ma zircons almost exclusively. Apart from the presence of rare Neoproterozoic zircons, the age spectra of the younger Adelaidean rocks are similar to those from the Skelton Group. Samples from the northern Skelton Group most closely resemble the uppermost Bonney Sandstone, while the southern Skelton Group sample most closely resembles the immediately underlying Marino Arkose (Ireland et al. 1998), indicating source terranes with remarkably similar ages. If the Skelton Group and Beardmore Group are correlatives of the Adelaidean succession, deposition of the northern and southern parts of the Skelton Group must have occurred at ca. 700-600 and $>700 \mathrm{Ma}$, respectively.

Source and Significance of Grenville Age Zircons in Neoproterozoic Basement to the Ross and Delamerian Orogens. The abundance of Grenville age zircons in sedimentary rocks deposited along the Neoproterozoic margin of East Antarctica and Australia requires a source terrane(s) of equivalent age and substantial extent. Mesoproterozoic rocks occur widely in southwest and central Australia (Clark et al. 2000; Fitzsimons 2000, 2003; Preiss 2000; Duebendorfer 2002), but no Grenville age igneous or metamorphic rocks have been identified in the Transantarctic Mountains, even in areas where widespread dating has accompanied mapping (fig. 6; Goodge and Fanning 1999; Goodge et al. 2001, 2002). Sample AA195/86 from the northern Skelton Group, which has a particularly restricted range of detrital zircon ages with a combined weighted mean age of $1049 \pm 11 \mathrm{Ma}$, is most likely a metasedimentary rock derived from a single or multiple plutons of the same petrogenetic suite. An alternative interpretation based on the restricted range of zircon ages is that the sample represents a slice of Grenville age granodioritic orthogneiss interlayered with younger Skelton Group rocks whose original texture and field relationships have been erased during multiple phases of deformation and metamorphism. If so, this would be the first evidence of Grenville age igneous rocks in the Ross Orogen, and this and any other related rocks could be a source of ca. 1050-Ma zircons in other samples from the Skelton Group.

Assuming AA195/86 is not an orthogneiss, other potential sources of Grenville age zircon in East 


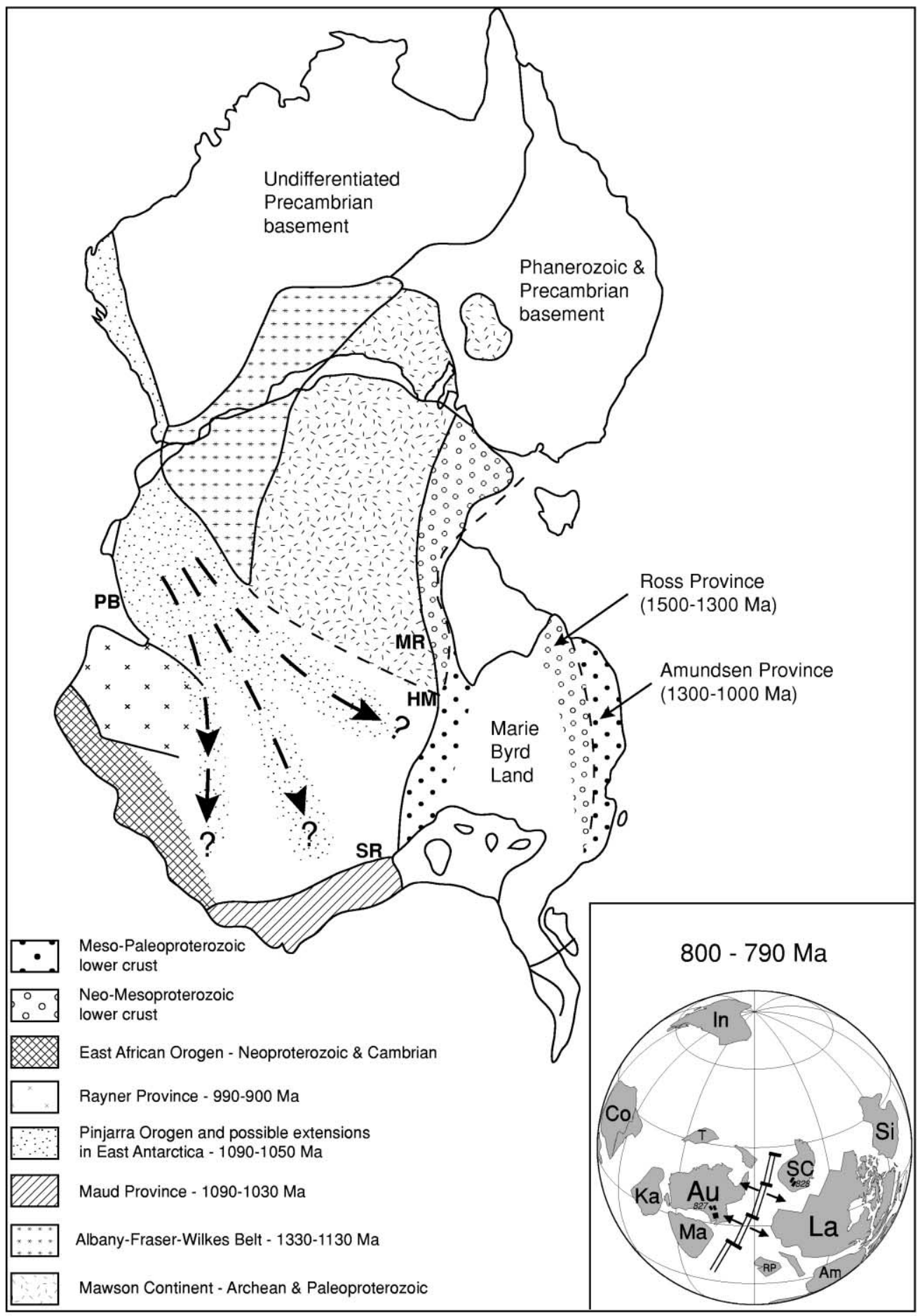

Figure 6. Inferred extent of major Precambrian basement provinces within East Antarctica and Australia (map after Fitzsimons 2003; inset after Pisarevsky et al. 2003; Ross and Amundsen Provinces after Pankhurst et al. 1998). Potential known source terranes for the Grenville age component in the Skelton and Beardmore Groups are located on the opposite side of the Archean-Paleoproterozoic Mawson Continent or the opposite margin of East Antarctica. The dashed line represents three possible extensions of the Pinjarra Orogen into East Antarctica (Fitzsimons 2003). HM, Horlick Mountains; MR, Miller Range; $P B$, Prydz Bay; SR, Shackelton Range. Inset: Am, Amazonia; Au, Australia; Co, Congo; In, India; Ka, Kalahari; La, Laurentia; Ma, Mawson Continent; RP, Rio de la Plata; SC, South China; Si, Siberia; $T$, Tarim. 
Antarctica are restricted to the opposite side of the Mawson Continent from the Skelton and Beardmore Groups (fig. 6). Widespread ca. 1050-Ma igneous rocks whose ages are similar to zircons that comprise a large part of the detrital population in the Skelton Group are present only in the Pinjarra Orogen and Maud Province (fig. 6; Fitzsimons 2000, 2003). Detritus from the Pinjarra Orogen must have crossed the Archean-Paleoproterozoic Mawson Continent (Fanning et al. 1995, 1996; Goodge and Fanning 1999; Goodge et al. 2001) to reach the Skelton Group (fig. 6). Zircons from such a distal source would likely form only a minor part of the detrital zircon population in sediments deposited by such an extensive drainage system (Cawood et al. 2003). The near absence of Paleoproterozoic and Archean zircons but abundance of ca. 1050-Ma zircons within the northern part of the Skelton Group argue against such a distal source. A source in the Maud Province or Pinjarra Orogen would require major strike-slip offset along the margin of East Antarctica during the Neoproterozoic, a possibility suggested for the Beardmore Group by Borg and DePaolo (1994).

Recent paleomagnetic constraints on the relative positions of Australia, Laurentia, and East Antarctica in Neoproterozoic time imply the juxtaposition of East Antarctica with the Grenville Province of southern Laurentia (AUSMEX construction; Wingate and Giddings 2000; Pisarevsky et al. 2003). The AUSMEX reconstruction is consistent with Grenville age zircons in the Skelton, Beardmore, and Adelaidean sediments being derived from Laurentia, provided that sedimentation preceded breakup of East Antarctica and Laurentia by 820 $800 \mathrm{Ma}$ (Pisarevsky et al. 2003). Mafic igneous rocks emplaced during deposition of the southern part of the Skelton Group and Beardmore Group imply that sedimentation occurred at ca. 750 and ca. $670 \mathrm{Ma}$, respectively, after the initiation of rifting between East Antarctica and southern Laurentia. Neoproterozoic sediments deposited at these times in East Antarctica could not have a Laurentian source unless they contain recycled material deposited before breakup at 820-800 Ma.

$\mathrm{Nd} \mathrm{T}_{\mathrm{DM}}$ model ages of some ca. 500-Ma-old granitoid rocks in southern Victoria Land (Cox et al. 2000), the Gabbro Hills area in the central Transantarctic Mountains (Borg et al. 1990), and the Horlick Mountains (fig. 6) at the southern end of the Ross Sea (Borg and DePaolo 1994) range between ca. 1500 and $1000 \mathrm{Ma}$. Remaining granitoid rocks in Victoria Land have $\mathrm{Nd} \mathrm{T}_{\mathrm{DM}}$ model ages of ca. 2100-1500 Ma, indicating pre-Grenville age basement in these areas (Borg et al. 1990; Rocchi et al. 1998; Vincenzo and Rocchi 1999). Granitoids with Mesoproterozoic $\mathrm{Nd} \mathrm{T}_{\mathrm{DM}}$ ages (1500-1000 Ma) also occur in Marie Bryd Land (Pankhurst et al. 1998). In all these regions, Os isotopic studies have identified substantial Neoproterozoic, Mesoproterozoic, and older mantle depletion events indicating mantle melting and potential crust formation events (Handler et al. 1997; Handler and Bennett 2001; Handler et al. 2003a, 2003b). Grenville age basement rocks in these areas may be isolated fragments of the Grenville Orogen thinned during Neoproterozoic extension rather than allochthonous terranes placed in their current position after ca. $750 \mathrm{Ma}$ (Borg and DePaolo 1994). These represent another potential source for the widespread Grenville age detritus in the Skelton, Beardmore, and Adelaidean rocks.

\section{Conclusions}

The abundant ca. 505-480-Ma Cambro-Ordovician zircons in samples from the Taylor Valley formed during partial melting that coincided with upper amphibolite facies metamorphism of the northern part of the Skelton Group. Apparently, concordant ages between ca. 900 and $550 \mathrm{Ma}$ reflect overlap of the SHRIMP beam on Precambrian and CambroOrdovician domains in the zircons, emphasizing the care needed to obtain good CL images before analysis and use them as guides to prevent beam overlap. Magmatic events between 900 and $500 \mathrm{Ma}$ do not appear to have occurred in the source terrane(s) of the Skelton Group. Detrital zircon ages indicate deposition of the northern and southern parts of the Skelton Group after ca. 1050 and 950 $\mathrm{Ma}$, respectively. The presence of pillow lavas with ca. 750-Ma Nd model ages interlayered with sedimentary rocks in the southern part of the Skelton Group (Rowell et al. 1993) suggests that at least part of the Skelton Group was deposited at this time.

The provenance of the southern part of the Skelton Group is mirrored in the detrital zircon ages of the Beardmore Group, although the relative proportions of particular zircon ages are different. The more restricted range of detrital zircon ages in the northern part of the Skelton Group implies a distinct provenance. Detrital zircon ages from the northern and southern parts of the Skelton Group closely resemble those of the Bonney Sandstone and underlying Marino Arkose, respectively, within the Adelaidean succession of South Australia (Ireland et al. 1998). These correlations imply deposition of the northern Skelton Group between 
ca. 700 and $600 \mathrm{Ma}$ and the southern Skelton Group $>$ ca. $700 \mathrm{Ma}$.

Grenville age zircons are a major component of the detrital zircon population of the Skelton Group and other basement units of the Ross and Delamerian Orogens. An extensive viable source terrane of this age has not been identified for these rocks in East Antarctica, although a quartzofeldspathic gneiss, interpreted as part of the Skelton Group but with a particularly restricted zircon assemblage indicating a protolith age of $1049 \pm 11 \mathrm{Ma}$, may be a granodioritic orthogneiss intercalated with sedimentary rocks. If so, this rock and any undiscovered orthogneisses of this age within the metasedimentary basement of the Ross Orogen are one potential source of Grenville age detrital zircons in the Skelton and Beardmore Groups. Potential Grenville age basement along the margin of East Antarctica, eastern Australia, and beneath Marie Byrd Land are alternative sources for the Grenville age zircons in the basements rocks of the Ross and Delamerian Orogens.

\section{A C K N O W L E D G M E N T S}

Collection of samples during 1986 was made possible by the New Zealand Antarctic Division, Department of Scientific and Industrial Research, University of Otago, Department of Geology Antarctic Program, and VXE6 Squadron, U.S. Navy. Assistance in the field was provided by A. Daly and M. Wenden. R. Norris, D. Craw, and A. Cooper provided many useful insights during discussion of this and related projects undertaken on samples from the Taylor Valley during the past 16 years. The sample from Mount Huggins was generously provided by Y. Cook and D. Craw. We would like to thank M. Fukuda for her drafting expertise and the Research School of Biological Sciences, Australian National University, and staff for use of their CL facilities. We are grateful to G. Gehrels, T. Ireland, and S. Johnson for providing comments that enhanced past versions of this article and to A. Cooper and J. L. Crowley for constructive critical reviews.

\section{REFER E N C E S C I T E D}

Adams, C. J. 1986. Age and ancestry of the metamorphic rocks of the Wilson Group of the Daniels range, USARP Mountains, Antarctica. In Stump, E., ed. Geological investigations in Northern Victoria Land. Am. Geophys. Union Antarct. Res. Ser. 46:25-38.

Allibone, A. H. 1988. Koettlitz Group. M.S. thesis, University of Otago, Dunedin.

. 1992. Low pressure/high temperature metamorphism of Koettlitz Group schists in the Taylor Valley and Ferrar Glacier area, South Victoria Land, Antarctica. N. Z. J. Geol. Geophys. 35:115-127.

Allibone, A. H.; Cox, S. C.; Graham, I. J.; Smillie, R. W.; Johnstone, R. D.; Ellery, S. G.; and Palmer, K. $1993 a$. Granitoids of the Dry Valleys region, southern Victoria Land, Antarctica: plutons, field relations and isotopic dating. N. Z. J. Geol. Geophys. 36:281-297.

Allibone, A. H.; Cox, S. C.; and Smillie, R. W. $1993 b$. Granitoids of the Dry Valleys region, southern Victoria Land, Antarctica: geochemistry and evolution along the early Paleozoic Antarctic Craton margin. N. Z. J. Geol. Geophys. 36:299-316.

Allibone, A. H.; Forsyth, P. J.; Sewell, R. J.; Turnbull, I. M.; and Bradshaw, M. A. 1991. Geology of the Thundergut area, southern Victoria Land, Antarctica: geology and geophysics division. N. Z. Dep. Sci. Ind. Res. Misc. Ser. Map 21, 1 sheet, 59 p., scale $1: 50,000$.

Allibone, A. H., and Norris, R. J. 1992. Segregation of leucogranite microplutons during syn-anatectic deformation: an example from the Taylor Valley, Antarctica. J. Metamorph. Geol. 10:589-600.

Allibone, A. H., and Wysoczanski, R. J. 2002. Initiation of magmatism during the Cambrian-Ordovician Ross
Orogeny in southern Victoria Land, Antarctica. Geol. Soc. Am. Bull. 114:1007-1018.

Black, L. P., and Sheraton, J. W. 1990. The influence of Precambrian source components on the U-Pb zircon age of a Paleozoic granite from northern Victoria Land, Antarctica. Precambrian Res. 46:275-293.

Borg, S. G., and DePaolo, D. J. 1994. Laurentia, Australia, and Antarctica as a Late Proterozoic supercontinent: constraints from isotopic mapping. Geology 22:307310.

Borg, S. G.; DePaolo, D. J.; and Smith, B. M. 1990. Isotopic structure and tectonics of the central Transantarctic Mountains. J. Geophys. Res. 95:6647-6667.

Brookfield, M. E. 1993. Neoproterozoic LaurentiaAustralia fit. Geology 21:683-686.

Burnett, C., and Berry, R. 2000. Proterozoic Australiawestern United States (AUSWUS) fit between Laurentia and Australia. Geology 28:103-106.

Cawood, P. A.; Nemchin, A. A.; Freeman, M.; and Sircombe, K. 2003. Linking source and sedimentary basin: detrital zircon record of sediment flux along a modern river system and implications for provenance studies. Earth Planet. Sci. Lett. 210:259-268.

Clark, D. J.; Hensen, B. J.; and Kinny, P. D. 2000. Geochronological constraints for a two-stage history of the Albany-Fraser Orogen, Western Australia. Precambrian Res. 102:155-183.

Cook, Y. 1997. The Skelton Group and the Ross Orogeny. Ph.D. thesis, University of Otago, Dunedin.

Cook, Y., and Craw, D. 2001. Amalgamation of disparate crustal fragments in the Walcott Bay-Foster Glacier 
area, South Victoria Land, Antarctica. N. Z. J. Geol. Geophys. 44:403-416.

. 2002. Neoproterozoic structural slices in the Ross Orogen, Skelton Glacier area, South Victoria Land, Antarctica. N. Z. J. Geol. Geophys. 45:133-143.

Cox, S. C. 1992. Garnet-biotite geothermometry of Koettlitz Group metasediments, Wright Valley, South Victoria Land, Antarctica. N. Z. J. Geol. Geophys. 35:2940.

- 1993. Inter-related plutonism and deformation in South Victoria Land, Antarctica. Geol. Mag. 130:1-14.

Cox, S. C.; Parkinson, D. L.; Allibone, A. H.; and Cooper, A. F. 2000. Isotopic character of Cambro-Ordovician plutonism, southern Victoria Land, Antarctica. N. Z. J. Geol. Geophys. 43:501-520.

Dalziel, I. W. D. 1991. Pacific margins of Laurentia and East-Antarctica-Australia as a conjugate rift pair: evidence and implications for an Eocambrian supercontinent. Geology 19:598-601.

Duebendorfer, E. M. 2002. Regional correlation of Mesoproterozoic structures and deformation events in the Albany-Fraser Orogen, Western Australia. Precambrian Res. 116:129-154.

Encarnacion, J., and Grunow, A. 1996. Changing magmatic and tectonic styles along the paleo-Pacific margin of Gondwana and the onset of early Paleozoic magmatism in Antarctica. Tectonics 15:1325-1341.

Fanning, C. M.; Bennett, V. C.; Moore, D. H.; and Daly, S. J. 1996. The "Mawson Continent": Archean to Proterozoic crust in the East Antarctic Shield and Gawler Craton, Australia: a cornerstone in Rodinia and Gondwana. Geol. Soc. Aust. Abstr. 41:135.

Fanning, C. M.; Daly, S. J.; Bennett, V. C.; Menot, R.-P.; Peucat, J.-J.; Oliver, R. L.; and Monnier, O. 1995. The "Mawson Block": once contiguous Archean to Proterozoic crust in the East Antarctic Shield and Gawler Craton, Australia. Proc. 7th Int. Symp. Antarct. Earth Sci., Siena, Abstr. 124.

Findlay, R. H.; Skinner, D. N. B.; and Craw, D. 1984. Lithostratigraphy and structure of the Koettlitz Group, McMurdo Sound, Antarctica. N. Z. J. Geol. Geophys. 27:513-536.

Fitzsimons, I. C. W. 2000. Grenville-age basement provinces in East Antarctica: evidence for three separate collisional orogens. Geology 28:879-882.

- 2003. Proterozoic basement provinces of southern and southwestern Australia, and their correlation with Antarctica. In Yoshida, M.; Windley, B. F.; and Dasgupta, S., eds. Proterozoic East Gondwana: supercontinent assembly and breakup. Geol. Soc. Lond. Spec. Publ. 206:93-130.

Flottmann, T.; Gibson, G. M.; and Kleinschmidt, G. 1993. Structural continuity of the Ross and Delamerian Orogens in Antarctica and Australia along the margin of the paleo-Pacific. Geology 21:319-322.

Foden, I.; Sandiford, M.; Dougherty-Page, J.; and Williams, I. 1999. Geochemistry and geochronology of the Rathjen Gneiss: implications for the early tectonic evolution of the Delamerian Orogen. Aust. J. Earth Sci. 46:377-389.
Goodge, J. W. 1997. Latest Neoproterozoic basin inversion of the Beardmore Group, central Transantarctic Mountains, Antarctica. Tectonics 16:682-701.

Goodge, J. W., and Fanning, C. M. 1999. 2.5 b.y. of punctuated Earth history as recorded in a single rock. Geology 27:1007-1010.

Goodge, J. W.; Fanning, C. M.; and Bennett, V. C. 2001. $\mathrm{U}-\mathrm{Pb}$ evidence of $\sim 1.7 \mathrm{Ga}$ crustal tectonism during the Nimrod Orogeny in the Transantarctic Mountains, Antarctica: implications for Proterozoic plate reconstructions. Precambrian Res. 112:261-288.

Goodge, J. W.; Myrow, P.; Williams, I. S.; and Bowring, S. A. 2002. Age and provenance of the Beardmore Group, Antarctica: constraints on Rodinia supercontinent breakup. J. Geol. 110:93-406.

Gravestock, D. I., and Shergold, J. H. 1999. Australian Early and Middle Cambrian sequence biostratigraphy with implications for species diversity and correlation. In Zhuralev, A., and Riding, R., eds. Ecology of the Cambrian Radiation. New York, Columbia University Press, p. 107-136.

Grindley, G. W., and McDougall, I. 1969. Age and correlation of the Nimrod Group and other Precambrian rock units in the Central Transantarctic Mountains, Antarctica. N. Z. J. Geol. Geophys. 12:391-411.

Grindley, G. W., and Warren, G. 1964. Stratigraphic nomenclature and correlation in the western part of the Ross Sea. In Adie, R. J., ed. Antarctic geology. Amsterdam, North Holland Publishing, p. 314-333.

Gunn, B. M., and Warren, G. 1962. Geology of Victoria Land between the Mawson and Mulock Glaciers, Antarctica. N. Z. Geol. Surv. Bull. 71, 157 p.

Hallsworth, C. R.; Morton, A. C.; Claoue-Long, J.; and Fanning, C. M. 2000. Carboniferous sand provenance in the Pennine Basin, UK: constraints from heavy mineral and detrital zircon age data. Sediment. Geol. 137: 147-185.

Hanchar, J. M., and Millar, C. F. 1993. Zircon zonation patterns as revealed by cathodoluminescence and backscattered electron images: implications for interpretation of complex crustal histories. Chem. Geol. 110:1-13.

Handler, M. R., and Bennett, V. C. 2001. Constraining continental structure by integrating Os isotopic ages of lithospheric mantle with geophysical and crustal data: an example from southeastern Australia. Tectonics 20:177-188.

Handler, M. R.; Bennett, V. C.; and Esat, T. M. 1997. The persistence of off-cratonic lithospheric mantle: Os isotopic systematics of variably metasomatised southeast Australian xenoliths. Earth Planet. Sci. Lett. 151: 61-75.

Handler, M. R.; Wysoczanski, R. J.; and Gamble, J. A. 2003a. Evolution of the Paleo-Pacific Gondwana margin: integrating lithospheric mantle Os ages from east Australia and West Antarctica. Jpn. Earth Planet. Sci. Joint Meet. Abstr.

—. 2003b. Proterozoic lithosphere in Marie Bryd Land, West Antarctica: Re-Os systematics of spinel peridotite xenoliths. Chem. Geol. 196:131-145. 
Hoffman, P. F. 1991. Did the breakout of Laurentia turn Gondwanaland inside out? Science 252:1409-1412.

Ireland, T. R. 1992. Crustal evolution of New Zealand: evidence from age distributions of detrital zircons in Western Province paragneisses and Torlesse greywacke. Geochim. Cosmochim. Acta 56:911-920.

Ireland, T. R.; Flöttman, T.; Fanning, C. M.; Gibson, G. M.; and Preiss, W. V. 1998. Development of the early Paleozoic margin of Gondwana from detrital-zircon ages across the Delamerian Orogen. Geology 26:243246.

Karlstrom, K. E.; Ahall, K.-I.; Harlan, S. S.; Williams, M. W.; McLelland, J.; and Geissman, J. W. 2001. Long lived $(1.8-1.0 \mathrm{Ga})$ convergent orogen in southern Laurentia, its extensions to Australia and Baltica and implications for redefining Rodinia. Precambrian Res. 111:5-30.

Li, Z. X.; Zhang, L.; and Powell, C. McA. 1995. South China in Rodinia: Part of the missing link between Australia-East Antarctica and Laurentia? Geology 23: 407-410.

Mellish, S. D.; Cooper, A. F.; and Walker, N. W. 2002. The Panorama pluton: a composite gabbro-monzonite, early Ross Orogeny intrusion in southern Victoria Land, Antarctica. In Gamble, J., and Skinner, D. N. B., eds. Proc. 8th Int. Antarct. Earth Sci. Symp. Victoria University of Wellington, New Zealand, p. 129141.

Moores, E. M. 1991. Southwest U.S.-East Antarctic (SWEAT) connection: a hypothesis. Geology 19:425428.

Myrow, P. M.; Pope, M. C.; Goodge, J. W.; Fischer, W.; and Palmer, A. R. 2002. Depositional history of preDevonian strata and timing of Ross Orogenic tectonism in the central Transantarctic Mountains, Antarctica. Geol. Soc. Am. Bull. 114:1070-1088.

Nair, R., and Chacko, T. 2002. Fluid-absent melting of high-grade semi-pelites: P-T constraints on orthopyroxene formation and implications for granulite genesis. J. Petrol. 43:2121-2142.

Paces, J. B., and Miller, J. D. 1993. Precise U-Pb ages of the Duluth Complex and related mafic intrusions, Northeastern Minnesota: geochronological insights to physical, petrogenetic, paleomagnetic and tectonomagmatic processes associated with the 1.1 Ga midcontinent rift system. J. Geophys. Res. 98B:13,99714,013 .

Pankhurst, R. G.; Weaver, S. D.; Bradshaw, J. D.; Storey, B. C.; and Ireland, T. R. 1998. Geochronology and geochemistry of pre-Jurassic superterranes in Marie Byrd Land, Antarctica. J. Geophys. Res. 103:2529-2547.

Pisarevsky, S. A.; Wingate, M. T. D.; Powell, C. M. C. A.; Johnson, S.; and Evans, D. A. D. 2003. Models of Rodinia assembly and fragmentation. In Yoshida, M.; Windley, B. F.; and Dasgupta, S., eds. Proterozoic East Gondwana: supercontinent assembly and breakup. Geol. Soc. Lond. Spec. Publ. 206:35-55.

Preiss, W. V. 2000. The Adelaide geosyncline of South Australia and its significance in Neoproterozoic continental reconstruction. Precambrian Res. 100:21-63.
Read, S. E.; Cooper, A. F.; and Walker, N. W. 2002. Geochemistry and U-Pb geochronology of the Neoproterozoic-Cambrian Koettlitz Glacier Alkaline Province, Royal Society Range, Transantarctic Mountains, Antarctica. In Gamble, J., and Skinner, D. N. B., eds. Proc. 8th Int. Antarct. Earth Sci. Symp. Victoria University of Wellington, New Zealand, p. 143-151.

Rocchi, S.; Tonarini, S.; Armienti, P.; Innocenti, F.; and Manetti, P. 1998. Geochemical and isotopic structure of the early Paleozoic active margin of Gondwana in northern Victoria Land, Antarctica. Tectonophysics 284:261-281.

Ross, G. M.; Parrish, R. R.; and Winston, D. 1992. Provenance and $\mathrm{U}-\mathrm{Pb}$ geochronology of the Mesoproterozoic Belt Supergroup (northwest United States): implications for age of deposition and pre-Panthalassa plate reconstructions. Earth Planet. Sci. Lett. 113:5776.

Rowell, A. J.; Rees, M. N.; Duebendorfer, E. M.; Wallin, E. T.; van Schmus, W. R.; and Smith, E. I. 1993. An active Neoproterozoic margin: evidence from the Skelton Glacier area, Transantarctic Mountains. J. Geol. Soc. Lond. 150:677-682.

Sears, J. W., and Price, R. A. 1978. The Siberian connection: a case for the Precambrian separation of the North American and Siberian cratons. Geology 6:267270.

- 2000. New look at the Siberian connection: no SWEAT. Geology 28:423-426.

Skinner, D. N. B. 1982. Stratigraphy and structure of lower-grade metasediments of Skelton Group, McMurdo Sound: does Teall Greywacke really exist? In Craddock, C., ed. Antarctic geoscience. Madison, University of Wisconsin Press, p. 555-563.

Smillie, R. W. 1992. Suite subdivision and petrological evolution of granitoids from the Taylor Valley and Ferrar Glacier region, South Victoria Land. Antarct. Sci. 4:71-87.

Tulloch, A. J., and Kimbrough, D. L. In press. Paired plutonic belts in convergent margins and the development of high Sr/Y magmatism: the Peninsular Ranges Batholith of California and the Median Batholith of New Zealand. Geol. Soc. Am. Spec. Pap. (Gastil Vol.). Turnbull, I. M.; Allibone, A. H.; Heron, D. W.; and Forsyth, P. J. 1994. Geology of the St. Johns Range, southern Victoria Land. Inst. Geol. Nucl. Sci., Lower Hutt, New Zealand, Geological Map 14, 1 sheet, 52 p., scale $1: 50,000$.

Vincenzo, G., and Rocchi, S. 1999. Origin and interaction of mafic and felsic magmas in an evolving late orogenic setting: the Paleozoic Terra Nova Intrusive Complex, Antarctica. Contrib. Mineral. Petrol. 137: 15-35.

Waters, D. J. 1988. Partial melting and the formation of granulite facies assemblages in Namaqualand, South Africa. J. Metamorph. Geol. 6:387-405.

Williams, I. S., and Claesson, S. 1987. Isotopic evidence for the Precambrian provenance and Caledonian metamorphism of high grade paragneisses from the Seve 
Nappes, Scandinavian Caledonides. II. Ion microprobe zircon U-Th-Pb. Contrib. Mineral. Petrol. 97:205-217.

Wingate, M. T. D.; Campbell, I. H.; Compston, W.; and Gibson, G. M. 1998. Ion microprobe U-Pb ages for Neoproterozoic basaltic magmatism in south-central Australia and implications for the breakup of Rodinia. Precambrian Res. 87:135-159.

Wingate, M. T. D., and Giddings, J. W. 2000. Age and paleomagnetism of the Mundine Well dyke swarm, Western Australia: implications for an AustralianLaurentian connection at $755 \mathrm{Ma}$. Precambrian Res. 100:335-357.

Wysoczanski, R. J.; Forsyth, P. J.; and Woolfe, K. J. 2003. Zircon dating and provenance of rhyolite clasts in Beacon conglomerate, southern Victoria Land, Antarctica. Terra Antarct. 10:65-78. 